\title{
Preface
}

\section{Encountering the Void}

I t is always difficult to explain when exactly the idea for any critical inquiry or intellectual project first began. Though, looking back, it seems clear to me that the impetus for this manuscript can be traced to 2010. During the summer I spent a number of months on the Greek island of Kefalonia and in the city of Florence. Being in close proximity to the place that inspired one of the greatest myths of all-the Odyssey-one learns the importance of light and color, which in turn allows us to make sense of the historical political imagination of the region. Greek mythology was always far more vivid than the pious dullness of Christianity that followed many of its vibrant tales. My intellectual companions at the time of my travels were René Girard's Violence and the Sacred, Giorgio Agamben's Homo Sacer, ${ }^{2}$ along with Walter Benjamin's Reflections, which featured his remarkable and challenging essay "Critique of Violence."”

My intention was to write a short meditation on the theme of "extreme violence," to be presented at a workshop on "politics after the death of God" when I returned. My hope was to submit it to a journal afterward. I never managed to complete this paper, for reasons I couldn't quite understand at the time. While I now recognize I was perhaps too intimidated by the topic, notably by coming to terms with the thought of Agamben and Benjamin, I had also reached a certain limit insomuch as I felt that when it came to explaining the worst, the most extreme, the most intolerable, there was seemingly nowhere left to go after Agamben's ruminations. I felt I was simply repeating what he had already said about the "unspeakable" violence done to fellow humans, and I feared that my explanation had nothing original to contribute. I now see my problem was that I was too constrained by my own methods. Biopolitically allegiant, I was too 
focused on bodies rather than on the psychic life of violence and what this might have revealed about the aesthetics of annihilation.

Being in Florence didn't help my predicament, though it did give me the time to properly read Dante's Inferno ${ }^{4}$ and try to make sense of its significance to the world at the time of its writing. I certainly appreciated that back then, as now, any serious critique of sacred violence needed to account for Dante's poetic reverie and its lasting images of thought. It is hard not to feel inspired in Florence. The entire place is like an open-gallery testament to the power of art. That's its enduring claim. But that was also the problem. Florence is a living testimony to the power of figurative art. Bodies in all their most perfect and monstrous forms appear everywhere. Indeed, while I walked through the Florentine plazas, gazing upon giant figures straight from some Classical Greek tale-expecting at any moment for one of them to come alive, step down off its concrete plinth, and walk through its narrow streets-I reflected on how the eternal memory of this City is all about embodiment.

And yet it was during this period that I did at least come to better appreciate the violence of the sacred. I had already accepted the idea that to understand violence one must first understand its sacred claims. This was equally true in the present day, as the legacy of just war was being countered by the most savage spectacles of human sacrifice. But I also understood, like racial persecution, this to be simply another chapter in the history of sacred violence. Modernity I accepted was nothing more than a continuation of pronounced theological notions, which continued to demand their own sacrifices. Not only this, I also felt completely dismayed by the positivism of political science, its secular claims of reason and objectivity, along with how its engagements-especially with violence-might become so much more compelling if it simply attended more to the power of art, aesthetics, and the literary imagination. Furthermore, I also recognized how some critical theory was opening up to new "poetic" terrains, where it was at least possible to consider alternative grammars in our inquiries. This might allow for a rethinking of the history of violence in more purposeful and all too human ways.

Mindful of this, and in light of the ongoing slaughter and other acts of violence perpetrated on a daily basis around the world, I came to think more about the relationship between humanity and violence, which I increasingly saw in theological terms. A number of questions would become of notable concern to me, and would actually form the basis of the initial book proposal, which I discussed with Wendy Lochner at Columbia University Press (to whom I owe an infinite 
debt for her patience with my endless delays for submission) back in 2015 when the contract was signed. Recognizing the importance of sacred motifs in the continuation of violence, I felt compelled to investigate how metaphysical claims to violence needed to appropriate suffering in order to justify its enactment in the name of some mythical project. Just as the violence of Christianity, for example, needed the body of Christ, so the Nation needed the body of the hero, while claims to Humanity needed the suffering body of the victim. This need to turn victims into sacred objects was, I believed, the poetic truth of humanitarian war, which, resurrecting theological notions of just violence, also presented humanity before us as an endangered and violated form. The questions guiding the initial research were therefore as follows:

1. What is the relationship between violence and sacrifice?

2. What do we actually mean when we say the word "humanity" (which includes the concept of race as a chapter in the history of sacred violence)?

3. How do we make sense of the ways in which liberal conceptions of humanity have justified violence in its name?

4. Why has the victim appeared so central to this drama?

5. What does this tell us about the order of the sacred in the contemporary world?

In the years that followed, I wrote a number of other books which dealt with ideas on the poetic, ${ }^{5}$ while pursuing the idea of intolerable violence. ${ }^{6}$ And yet something was still preventing me from completing this project. I kept coming up against limits in my own thinking and found that I simply didn't have the language or conceptual tools to really say what I wanted to convey. In truth, I found myself in a state of intellectual limbo, no doubt haunted by the intellectual anxieties of 2010, still trying to say something more than just a final chapter in the theological history of biopolitics and the violence enacted because of some sacred claim. But all was not lost. I had admittedly made a number of breakthroughs in my thinking as a result of columns I was invited to lead in both the New York Times and the Los Angeles Review of Books, ${ }^{7}$ which gave me the freedom to engage more openly in conversation with critical theorists, artists, and writers, to whom I owe a considerable intellectual debt with regard to my reconceptualizing violence and rethinking aesthesis. 
Still, it was only after meeting the Mexican abstract painter Chantal Meza (who is now my wife) that I truly recognized the nature of my problem. Or, to put it more explicitly, my problem was that I literally couldn't see the problem. Yes, I recognized that our understating of sacred violence needed a more critical exposition, especially given the return of all too archaic forms of sacrifice across the world. And yes, I also recognized there was an urgent need to rethink more deeply the conceptual crises of humanity, especially if we were to counter the emergence of new forms of fascism that were evidently resurrecting older mythical claims. That book would have been completed in 2017. While I have no idea how it might have been received, I do strongly believe that the waiting has taken the project in a far more important and considered direction. For in the time that's followed I have realized the problem behind the problem. Blinded by the appearance of bodies wrapped in blood-soaked mythical shrouds, I hadn't seen what actually gives rise to the sacred, giving true justification to its importance in response to political animality. If violence was something original in the order of sacred meaning, then I needed to properly consider what lay behind in the absence of its appearance. It took somebody with a brilliant aesthetic eye to make this clear to me, moving forward.

Engaging with Chantal's art and discussing aesthetics from the artist's perspective with her allowed me to recognize more attentively and with greater appreciation the importance of abstraction and how it provides a point of entry into the intimate depths of suffering. I was notably taken by the circularity of the violent lines she painted, which tore into the canvas, allowing me to rethink the violence of movement and the flight from history. Then, in 2018, Chantal and I went to visit the Tate Modern gallery in London. The gallery was notably full of people who spent a few brief seconds marvelling at whatever exhibit appeared before them, without any time for critical reflection. As we weaved through the madding crowds, our wandering eventually led us into the thankfully empty room housing Mark Rothko's Seagram Murals. We spent an afternoon immersed in the intensity of his brilliant works, commenting on the violence and the pain they conveyed, the internal suffering and the depths of despair, the subtle light and the darkened vortexes, the eternal optimism and the worldly tragedies yet to come.

Our conversation continued in the evening as to the reasons why we still haven't properly understood the power of his intervention, how the sacred is present and disrupted in his cathedrals of the mind, about the historical crisis 
of the figurative and the need to take more seriously the abstract in thought. While constantly thinking about this project as the discussion developed, I was also learning how to appreciate the world-especially the aesthetic world of violence-through an artist's gaze. Not to simply appropriate some aesthetic point in order to reaffirm my own theoretical premise but to become a learned student, taking aesthetic notes on how to reimagine the power of critique. Then, finally, it became clear. Not only did Rothko paint the violence of the world in such an intimate way it brought into focus its sacred mediations and claims. Rothko painted "the void." This was the problem that was really haunting this project. And, armed with this understanding, I began to see what needed to be written in this book.

One afternoon, a few weeks later, I returned home after giving a lecture at the university on the importance of Hannah Arendt. Chantal had been working on a series of paintings titled "Obscure Beasts" which were part of her State of Disappearance series. ${ }^{8}$ I entered the apartment (where she was working) at the moment she was just finishing the final piece that day. She didn't even know I had entered the room. As Chantal lifted herself off the floor where the works were placed, she fell back into the armchair, her hands covered in deep-red and black paint. Her eyes were completely absent of any expression, and her face looked completely exhausted. While admittedly unsettled by this sight, I realized in that moment something else that was deeply significant about the book's problematic and how we might find an escape. The reason we don't like to confront the void is precisely because of the immensity of its terror. The unknown can be atrocious. And there is nothing more terrifying than nothingness. Yet, here was an artist painting about disappearance, the absence of absence, the voiding of existence, looking out after the creative process with such an absent gaze. It was as if she had willfully fallen into the void in order to imagine and create the world anew. This was a powerful realization. For if extreme violence results in us being thrown into void, which in itself is the absence which haunts and underwrites all forms of sacred meaning, this same void can also be a space of pure creation, where the immensity of terror and the affirmation of life collide.

There is, however, an inherent danger. How can one understand what's truly at stake if one can only confront the void with either torturously daemonic or artistic eyes? And how does one return without becoming a monstrous beast, seduced by the power of nihilism and its will to nothing? What had become clear was that in order to do justice to the idea, I must explore such a phenomenon 
as the pain of humanity; it wasn't sufficient to simply write about the sacred. More searching, there was a need to account for the pure potentiality of the void, which in turn affirmed the need for a more poetic understanding of the political in the face of annihilation, and the hope that we might finally break free from the myths that bind us.

My first reaction was to return to the works of Agamben and engage once again with his sacred mediations. While I had the same admiration for this thinking, what I found notable about his corpus-including Homo Sacer, State of Exception, Stasis, The Sacrament of Language, the Kingdom and the Glory, and his devastating Remnants of Auschwitz-was that it all contained rather fleeting reference to the void. ${ }^{9}$ The concept does appear in a subtitle in State of Exception (though it is not conceptually developed beyond that one particular headline announcement), and is used very fleetingly elsewhere to describe a mere absence in law, language, or representation. There was also a brief moment in Kingdom and Glory where he suggested "the void is the sovereign figure of glory," but he only invoked the word to make a more considered point on the idea of the empty throne.

This same fleeting attention to the concept of the void was also apparent in Jean-Paul Sartre's Being and Nothingness, ${ }^{10}$ reserved for a very few mentions in respect to the voiding or absence of meaning. Wanting more, I eventually turned to the work of Georges Bataille, whose entire investigations centred on the void. ${ }^{11}$ Like Yves Klein, Bataille seemed to picture himself at the edge of the abyss. Welcoming the ineffable and the limits of the sacred calling, Bataille would find his freedom through horror. This led him to develop a theory of nothingness, which literally took nothing to be its object. That is, the object was to confront the dreadful apprehension of death and put oneself before the emptiness of the void. To achieve this, Bataille would find his escape through a return to sacrifice and the power of the sacred. But was this as radical as it appeared? My understanding already led me to believe that the history of Western metaphysics was defined by its allegiance to the sacred: the giving of oneself over to whatever myth appealed. And hence what needed to be accounted for was precisely how critics felt the need to fall back onto sacred ground, which for Bataille meant imagining one's own sacrifice in the name of radical alterity-quite literally pushing the sacred to its limits and over the edge. Although less provocative, this allegiance to sacrifice has since been apparent with many "post-secular" thinkers, who in their search for a more poetic understanding of the human condition only deepen further sacred claims. This added a number of further questions to the project: 
6. What is the relationship between sacred violence and the void?

7. How might we conceptualize the void in terms of its destructive and creative potentialities?

8. How might this allow us to provide a more meaningful critique of violence adequate to our times?

In the decade which had passed since the book's thesis was initially conceived, there were also notable political changes that needed to be accounted for in the intellectual body of the work. Just as global politics needed to come to terms with the devastating failures of liberal internationalism and its humanitarian wars, which had exposed most fully the racial violence at the heart of the European idea of modernity, so was the very idea of liberalism put into crisis. I had already written about this crisis in the context of the normalization of terror and the onset of the doctrine of resilience, ${ }^{12}$ which I argued was the final resting place for liberal subjectivity. Still, the tumultuous political events of the past few years made it increasingly clear that it was now possible to write an obituary for the liberal. If liberalism was a globally ambitious project aimed at governing planetary life through its sacred wars, this ambition was over. And, like all dying projects, its myths had been exposed, rendering its remaining advocates increasingly vicious in their desperation to cling onto whatever entitlements its violence once permitted. Hence-while the book had become an inquiry into the triangulation between violence, the sacred, and the void-it also needed to confront the end of liberal times:

9. How might we free the concept of humanity from its liberal chains?

10. How might we rethink the very idea of humanism after the death of liberalism?

11. What new mythical claims and sacred games will now be invented, and what violence will this permit?

12. How might we reimagine the future of the political without falling back upon some notion of sacred space?

Each of these questions had largely been dealt with upon completion of the first draft in early April 2020. But I felt that I perhaps hadn't gone far enough in my critique. Then, within a week, the world started to become aware of the tragic significance of the COVID-19 pandemic. As I watched the epicenter of the 
pandemic move from China to Italy, I was reminded once again of Florence and the bubonic plague, which occurred shortly after Dante's death. Surreptitiously imagined though probably just purely coincidental, as readers of this book will come to appreciate, while the poet would have a marked influence on my thinking, from its inception right through to the very end, so its year of publication also corresponds to the 7ooth anniversary of Dante's death. As the response to the pandemic unfolded, it became increasingly apparent that the postliberal order was already in the making. That is to say, while at the level of individual people there were remarkable displays of humanism witnessed, at the national level one could recognize the eerily familiar dominance of war narratives and their sacrificial rites.

But there was something different taking place. As every single metropolitan city became engulfed in a humanitarian crisis, it was increasingly apparent who were positioning themselves to be the new rulers in this state of emergency. We had known for some time about the marked separation between politics (at the level of nations) and power (into the global space of flows). But as the forces of militarism and state policing were now being matched by the tremendous acceleration of digital technology, and its involvement in our daily lives, what became crystal clear was that we were entering a new age that could be defined as a global techno-theodicy. And if this techno-theodicy accelerated the crisis of the victim, it also showed that the scapegoats would be precisely those who had the temerity to question the sacredness of technocratic reasoning and its post-political vision for a lasting planetary lockdown. Populist leaders were merely a sideshow, and in the end, showed to be just as disposable and expendable to the new technocrats of reason as anyone else. With this in mind, I needed to revise the manuscript in order to more fully address a problem that was already detected but not in focus enough prior to the pandemic.

The lockdown of 2020 didn't come to an end through some shared agreement on social responsibility and a new planetary awakening. The lockdown was torn apart by the brutal killing of George Floyd in Minneapolis, which once again revealed the deeply engrained racial violence present within Western societies. While the riots that followed seemed to speak to a population that was simply exhausted by the prejudice it faced, this event was also significant for a number of no less compelling reasons: 1) liberalism was never able to come to terms with the problem of race other than to violently police its existence. The birth of liberalism in fact corresponds with the birth of race as a lived reality and a political 
problem. The violence therefore showed how liberalism was no longer able to conceal this history, as 2) the Black Lives Matter movement started tearing down statues, notably in the United States and United Kingdom; it was clear that a new way of doing politics was being sought.

But even here it seemed that narratives of victimhood fell back upon notions of the sacred victim: 3 ) ostensible radical sympathies were often channeled primarily through rage-filled social media posts, which expressed the fight by highlighting the persistence of old symbols of power rather than the new dominating paradigm-namely the emerging techno-theodicy. Meanwhile, 4 ) while the question of race remained deeply important for rethinking the direction humanity might take, much of the debate was still all too predictable. Like the mythical assumption that violence was simply natural to the human species, so the question of racial intolerance also appeared timeless. Hence, while my understanding of violence was that it was only naturalized through its being bound to the sacred order of things, as I watched the Black Lives Matter drama unfold I especially felt that it was even more important that the lines of racial persecution were understood to be a distinct colonial invention. Racial violence, in short, was never timeless but in fact a more recent chapter in the history of sacred violence. And unless we understand how the sacred order has already transformed into something new, what is presented as resistance can so easily be appropriated.

Not unrelated to the question of race, there is another issue that must be acknowledged from the outset here. What I am referring to as the sacred order of politics does work within a distinct Eurocentric frame. Indeed, the move from the sacrificial violence of the Greeks to the body of Christ takes us on the road to Jerusalem, which would literally become the center of the earth in many early forms of worldly mapping and representations of power. Moreover, the moves from Christianity to colonization, and onto the nation-state and liberalism, operate within the European framework for sacred thinking. This is not, however, incidental. It is precisely this order of the sacred which has come to dominate the structure for power and violence in the world.

In contrast, it is my contention that "the void" is by definition aterritorial. Indeed, as early Japanese paintings such as Sesshū Tōyō's Haboku Sansui-literally "Broken Ink Landscape"-(1495) show (fig. I.1), the concern with the abstract and the question of absence, along with how it relates to presence, have a poetic history that far predates the European invention of the aesthetic terms. The dominant signifiers for the sacred in their current form represent a continuation of 




Fig. I.1 Sesshū Tōyō, Haboku Sansui. 1495. Ink on paper. Public domain.

the European imaginary, which is able to rework its mythical binds as the forces of history bring the particularities of the sacred into question. However, the creative potential of the void is anti-identarian in the sense that it disavows any authentic claim to righteously call upon the fire from its alluring black sun. 
This book certainly doesn't claim to answer all of these questions outlined above to satisfy the doubters. And I have no doubt some will criticize it for being too general, while others will self-righteously insist that I don't see the wider picture. I wrote this book in solitude. That was my curse, and I will have to reckon with its limitations. But once I began to see the problem, I was always more than one, especially when staring into the void. That was my comfort, to realize that I was never alone. And this has been truly instructive in terms of how I have rethought poetics as an ethical sensibility that's counter to the sacred in thought. Striking like a lightning bolt from wounded skies, this sensibility catalyzes an unexpected encounter with a love that demands no sacrifice. A love that accompanies and asks nothing in return. So if this book at least provokes some debate on the history of violence, its sacred claims, the meaning of the void, and why there's an urgent need to imagine a different image of the world to the one that is continuing to annihilate us, then that will be more than any author could have ever asked. In the words of Gaston Bachelard, "The repose of the night does not belong to us. It is not the possession of our being. Sleep opens within us an inn for phantoms. In the morning we must sweep out the shadows." 



\section{ECCE HUMANITAS<smiles>CCCCCCC(C)C</smiles> 
